\title{
The nature and combination of subunits used in epitope-based Schistosoma japonicum vaccine formulations affect their efficacy
}

Xuefeng Wang ${ }^{1,2 \dagger}$, Lei Zhang ${ }^{1 \dagger}$, Ying Chi', Jason Hoellwarth³ ${ }^{3}$ Sha Zhou' ${ }^{1}$ Xiaoyun Wen', Lei He ${ }^{1}$, Feng Liu', Calvin $\mathrm{Wu}^{3}$, Chuan $\mathrm{Su}^{1 *}$

\begin{abstract}
Background: Schistosomiasis remains a major public health problem in endemic countries and is caused by infections with any one of three primary schistosome species. Although there are no vaccines available to date, this strategy appears feasible since natural immunity develops in individuals suffering from repeated infection during a lifetime. Since vaccinations resulting in both Th1- and Th2-type responses have been shown to contribute to protective immunity, a vaccine formulation with the capacity for stimulating multiple arms of the immune response will likely be the most effective. Previously we developed partially protective, single Th- and B cellepitope-based peptide-DNA dual vaccines (PDDV) (T3-PDDV and B3-PDDV, respectively) capable of eliciting immune responses against the Schistosoma japonicum $22.6 \mathrm{kDa}$ tegument antigen (Sj22.6) and a $62 \mathrm{kDa}$ fragment of myosin (Sj62), respectively.

Results: In this study, we developed PDDV cocktails containing multiple epitopes of S. japonicum from Sj22.6, Sj62 and Sj97 antigens by predicting cytotoxic, helper, and B-cell epitopes, and evaluated vaccine potential in vivo. Results showed that mice immunized with a single-epitope PDDV elicited either Tc, Th, or B cell responses, respectively, and mice immunized with either the T3- or B3- single-epitope PDDV formulation were partially protected against infection. However, mice immunized with a multicomponent (3 PDDV components) formulation elicited variable immune responses that were less immunoprotective than single-epitope PDDV formulations.

Conclusions: Our data show that combining these different antigens did not result in a more effective vaccine formulation when compared to each component administered individually, and further suggest that immune interference resulting from immunizations with antigenically distinct vaccine targets may be an important consideration in the development of multicomponent vaccine preparations.
\end{abstract}

\section{Background}

Schistosomiasis is one of the most important neglected tropical diseases (NTDs) and remains a major public health problem in endemic countries [1,2]. Although schistosomiasis can be treated with praziquantel [3], the high re-infection rate limits the overall success of chemotherapy which typically needs to be readministered multiple times during the first two decades of life $[4,5]$.

\footnotetext{
* Correspondence: chuansu@njmu.edu.cn

+ Contributed equally

'Department of Pathogen Biology and Immunology, Jiangsu Key Laboratory of Pathogen Biology, Department of Pharmacology, Nanjing Medical

University, Nanjing, Jiangsu 210029, PR China

Full list of author information is available at the end of the article
}

Therefore, the development of a safe, effective vaccine could improve long-term control of schistosomiasis and improve the efficacy of chemotherapeutic interventions [6-8].

Vaccination with radiation-attenuated cercariae induced significant levels of resistance to schistosome challenge via Th1- and Th2-mediated responses in animal models of disease. However, multiple concerns regarding this method make it unsuitable for human use $[9,10]$. Considerable efforts have been aimed at the identification of relevant (immunoprotective) schistosome antigens resulting in the identification of potential vaccine targets $[6,11,12]$. The major challenge in the development of anti-schistosome vaccines is to use defined 
antigens to stimulate the appropriate immune response that lead to protection. Although the $S$. japonicum Sj22.6 [13], Sj62 [14], and Sj97 [15] antigens, which are all important components of schistosome adult worm antigens (SWA), have been shown to be promising vaccine candidates, other approaches have focused on eliciting specific B-cell and Th-cell responses by identifying different antigenic determinants in potential vaccine targets [16,17]. Epitope-based vaccines offer the prospect of targeted immunity resulting in safer and more effective antigen-specific immune responses [18]. Previously we developed partially protective Th-, and B-cell epitope vaccines derived from the Sj22.6 or Sj62 antigens, respectively. However, the levels of protection induced by both vaccines were limited.

In addition, type $\mathrm{I} \mathrm{CD}^{+} \mathrm{T}$ cells (effector $\mathrm{CD}^{+} \mathrm{T}$ cells), which produce INF- $\gamma$, have been proposed to play an immunoregulatory role during schistosomiasis by dampening immunopathologic type 2 responses $[19,20]$. Studies of the Sm28GST vaccine suggest that both $\mathrm{CD}^{+}$and $\mathrm{CD}^{+} \mathrm{T}$ cells might contribute to protection. Activation of Sm28GST-specific $\mathrm{CD}^{+} \mathrm{T}$ cells produced high levels of gamma interferon (IFN- $\gamma$ ) involved in protective immune responses, which suggest that $\mathrm{CD}^{+} \mathrm{T}$-cell response induced by an antigen from the extracellular parasite $S$. mansoni may protect the mice from infection [21,22].

Currently, there are numerous efforts focused on optimizing schistosome vaccines (and vaccines against other infectious agents) using multiple-antigen or multipleepitope design [23-26]. One strategy consists of designing subunit constructs containing defined B- and T-cell stimulatory epitopes obtained by genetic engineering or by chemical synthesis $[27,28]$. In some experimental models, anti-repetitive peptide responses have been able to confer immune protection against infection $[29,30]$.

In this report we used the full-length $S$. japonicum vaccine candidates $\mathrm{Sj} 22.6, \mathrm{Sj} 62$ and $\mathrm{Sj} 97$ to generate eight distinct computer-based eptiopes identified by their potential for eliciting Tc-, Th-, or B-cell responses, respectively, using computer-based epitope-predicting software. All eight epitopes (named C1, C2, C3, B1, B2, B3, T2 and T3) were synthesized and encapsulated with the corresponding recombinant eukaryotic plasmid DNA encoding the corresponding epitope, respectively, to construct a peptide-DNA dual vaccine (PDDV) that has an antigenic peptide "shell" and a plasmid "nuclei". These pseudotype virus-like particles have revealed tremendous potential as novel delivery systems to enhance cell-specific gene delivery $[31,32]$ and efficiently stimulate the host immune reponses $[33,34]$. We examined whether multicomponent PDDVs consisting of Tc (C)-, Th (T)- and Bcell (B) epitopes were more effective formulations against $S$. japonicum challenge than T- or B-cell single-epitope PDDVs. Our data showed that vaccination of mice with
single-epitope-PDDV elicited corresponding immune responses - i.e., cytotoxicity, proliferation, or antibody production, respectively - and that vaccination with T3or B3-PDDV induced partial protection. However, vaccination of mice with multicomponent PDDV formulations comprised of multiple epitopes produced variable immune responses that failed to induce better protection than T3- or B3- single-epitope PDDVs.

\section{Results}

\section{Epitopes and their encoding DNA sequences}

As shown in Table 1, eight candidate epitopes $(C 1, C 2$, $\mathrm{C} 3, \mathrm{~T} 2, \mathrm{~T} 3, \mathrm{~B} 1, \mathrm{~B} 2$, and $\mathrm{B} 3$ ), plus an $18 \mathrm{~K}$ tail respectively, were chosen based on their predicted antigenicity scores for the further examination of various anti-S. japonicum immune responses. The DNA sequences used to encode the respective $S$. japonicum epitopes were designed based on the published S. japonicum DNA sequences for Sj22.6 [13], Sj62 [14] and Sj97 [15].

\section{C2- and C3-PDDV induced the cytotoxic effect and} elicited antibody and IFN- $\gamma$ production in C57BL/6 mice Cytotoxic responses to epitopes predicted to elicit Tc responses were measured by immunizing mice with either C1-PDDV, C2-PDDV, or C3-PDDV. Control mice were immunized with either 18K-PDDV or PBS. Splenocytes harvested from immunized mice demonstrated that $\mathrm{C} 2$ - and C3-PDDV immunizations elicited the strongest cytotoxic responses (Figure 1A). A significant IgG response was elicited by $\mathrm{C} 2$ - and C3-PDDV (but not C1-PDDV or controls), and C2-PDDV-immunized mice also developed a significantly elevated IgG2a response. However IgG1 responses were not observed in mice immunized with any of the CTL-PDDV formulations (Figure 1B). Analysis of IFN- $\gamma$ (Figure 1C) and IL-4 (Figure 1D) production of cultured splenocytes from PBS, control 18K PDDV, C1-, C2-, or C3-PDDV vaccinated mice did not reveal significant increases in IL-4 production. However, following restimulation with the respective $\mathrm{C} 2$ - or $\mathrm{C} 3-18 \mathrm{~K}$ fusion peptide, a statistically significant increase in IFN- $\gamma$ production was observed compared to controls restimulated with medium or $18 \mathrm{~K}$ in vitro. These results indicate that $\mathrm{C} 2$ - and $\mathrm{C} 3-\mathrm{PDDV}$ vaccination induced cytotoxic responses associated with IFN- $\gamma$ production and IgG and IgG2a production.

\section{T3-PDDV induced both cellular and humoral immune responses in C57BL/6 mice}

To examine the immune responses induced by the T-PDDVs vaccination, both cellular and humoral immune responses were analyzed after the final vaccination. Only splenocytes harvested from T3-PDDV-vaccinated mice proliferated in response to $\mathrm{T} 3-18 \mathrm{~K}$ fusion peptide stimulation in comparison to $18 \mathrm{~K}$-peptide or medium stimulated 
Table 1 Design of peptides used in the construction of the PDDVs

\begin{tabular}{|c|c|c|c|c|}
\hline Code & $\begin{array}{l}\text { Amino acid sequence of } 18 \text { Lys and the } 18 \text { Lys } \\
\text { fused epitopes synthesized for PDDV } \\
\text { formulations }\end{array}$ & $\begin{array}{l}\text { Oligonucleotide sequences used for plasmid } \\
\text { construction }\end{array}$ & Source & $\begin{array}{l}\text { Epitope } \\
\text { type }\end{array}$ \\
\hline $18 \mathrm{~K}$ & ККККККККККККККККККК & None & None & None \\
\hline \multirow[t]{2}{*}{ C1 } & KKKKKKKKKKKKKKKKKKKNLMKENKNL & 5'-tcgacatgaatcttatgaaagaaaataagaatttag-3' & $\begin{array}{l}\text { Sj } 97 \\
(555-563)\end{array}$ & $C T L$ \\
\hline & & 5'-aattctaaattcttattttctttcataagattcatg-3' & & \\
\hline \multirow[t]{2}{*}{ C2 } & KKKKKKKKKKKKKKKKKKKVRAVANDLK & 5'-tcgacatggtaagagcggtggcaaatgacttaaaag-3' & $\begin{array}{l}\text { Sj 22.6 } \\
(134-142)\end{array}$ & $C T L$ \\
\hline & & 5'-aattcttttaagtcatttgccaccgctcttaccatg-3' & & \\
\hline \multirow[t]{2}{*}{ C3 } & KKKKKKKKKKKKKKKKKKKATRLNNEVL & 5'-tcgacatggcaactagattgaataatgaagttttgg-3' & $\begin{array}{l}\text { Sj } 97 \\
(672-680)\end{array}$ & $C T L$ \\
\hline & & 5'-aattccaaaacttcattattcaatctagttgccatg-3' & & \\
\hline \multirow[t]{2}{*}{$\mathrm{T} 2$} & KKKKKKKKKKKKKKKKKKITELEDVAERERLKA & $\begin{array}{l}5^{\prime} \text {-tcgacatgatcactgaacttgaagatgttgcagag } \\
\text { agagaacgattaaaagcgg-3' }\end{array}$ & $\begin{array}{l}\text { Sj } 97 \\
(313-327)\end{array}$ & Th-cell \\
\hline & & $\begin{array}{l}5^{\prime} \text {-aattccgcttttaatcgttctctctctgc } \\
\text { aacatcttcaagttcagtgatcatg-3' }\end{array}$ & & \\
\hline \multirow[t]{2}{*}{ T3 } & KKKKKKKKKKKKKKKKKKAKQYNICCKFKELLD & $\begin{array}{l}5^{\prime} \text {-tcgacatggctaagcaatataacatatgttg } \\
\text { taaatttaaagaacttctcgatg-3' }\end{array}$ & $\begin{array}{l}\text { Sj22.6 } \\
(111-125)\end{array}$ & Th-cell \\
\hline & & $\begin{array}{l}5^{\prime} \text {-aattcatcgagaagttctttaaatttac } \\
\text { aacatatgttatattgcttagccatg-3' }\end{array}$ & & \\
\hline \multirow[t]{2}{*}{ B1 } & KKKKKKKKKKKKKKKKKKKEQRLRERDEELESLRKSTTRTI & $\begin{array}{l}5^{\prime} \text {-tcgacatggaacagagacttagagaaagagatgaag } \\
\text { aattagaaagtctaagaaagagtacaactagaacaatattg-3' }\end{array}$ & $\begin{array}{l}\text { Sj } 97 \\
(489-510)\end{array}$ & B-cell \\
\hline & & $\begin{array}{l}5^{\prime} \text {-aattcaatattgttctagttgtcatctttcttagactttcta } \\
\text { attcttcatctctttctctaagtctctgttccatg-3' }\end{array}$ & & \\
\hline \multirow[t]{2}{*}{ B2 } & KKKKKKKKKKKKKKKKKKKWEVRREKEELKKDKEGKVSTL & $\begin{array}{l}5^{\prime} \text {-tcgacatgtgggaagtccgtcgtgaaaaggaagaatt } \\
\text { aaagaaagacaaggaaggcaaagtatccacacttg-3' }\end{array}$ & $\begin{array}{l}\text { Sj } 22.6 \\
(77-97)\end{array}$ & B-cell \\
\hline & & $\begin{array}{l}5^{\prime} \text {-aattcaagtgtggatactttgccttccttgtctttctttaa } \\
\text { ttcttccttttcacgacggacttcccacatg-3' }\end{array}$ & & \\
\hline \multirow[t]{2}{*}{ B3 } & KKKKKKKKККKКKKKKKKKRQEEEMKKAAEELAKLKEEFEK & $\begin{array}{l}5^{\prime} \text {-tcgacatgcgtcaggaagaagaaatgaagaaagcagecgaa } \\
\text { gaattagctaaactaaaagaagaatttgaaaaag-3' }\end{array}$ & $\begin{array}{l}\text { Sj } 62 \\
(167-188)\end{array}$ & B-cell \\
\hline & & $\begin{array}{l}5^{\prime} \text {-aattctttttcaaattcttcttttagtttagctaattcttcggct } \\
\text { gctttcttcatttcttcttcctgacgcatg-3' }\end{array}$ & & \\
\hline
\end{tabular}

controls (Figure 2A). Both T2- and T3-PDDV-immunized mice produced significant levels of IFN- $\gamma$ in the absence of in vitro restimulation with $\mathrm{T} 2$ - or $\mathrm{T} 3-18 \mathrm{~K}$ fusion peptide, suggesting that $\mathrm{T} 2$ and T3-PDDV vaccination induced specific Th1-type cellular immune responses in vivo. However, in vitro restimulation of splenocytes harvested from T3PDDV-vaccinated mice with $\mathrm{T} 3-18 \mathrm{~K}$ fusion peptide resulted in a significant increase of IFN- $\gamma$ production (Figure 2B). T3-PDDV-immunized mice also developed a significant IL-4 response following in vitro restimulation with the T3-18K fusion peptide, suggesting that T3-PDDV could also induce the production of a Th2-associated cytokine (Figure 2C). Compared to both control groups, only T3-PDDV-immunized mice developed significant antigenspecific IgG, IgG1, and IgG2a responses (Figure 2D). These results suggest that immunization with T3-PDDV induced both Th1/Th2 and antibody responses in C57BL/6 mice.

\section{B3-PDDV induced the highest antibody response in C57BL/6 mice}

To investigate the immune responses induced following immunization with the B-PDDV epitopes, mice were immunized with either B1-, B2- or B3-PDDV or the $18 \mathrm{~K}-\mathrm{PDDV}$ or PBS, respectively. Compared to the both $18 \mathrm{~K}-\mathrm{PDDV}$ and PBS control groups, all three B-PDDV groups developed significantly increased IgG responses. However, only B3-PDDV-immunized mice developed a significant IgG1 response (Figure 3A). Furthermore, only splenocytes harvested from B3-PDDV-immunized mice proliferated significantly in response to in vitro stimulation with the B3-18K fusion peptide (Figure 3B). Cytokine production analysis of supernatants showed that none of the B-PDDVs elicited significant increases in IFN- $\gamma$ or IL-4 production (Figure 3C and 3D) suggesting that these epitopes mainly elicited significant changes in antibody production.

\section{Cytokine and antibody responses in mice vaccinated with CTL-, T- and B-PDDV cocktails}

Previous studies have shown that $\mathrm{CD}^{+}$cells play a regulatory role in schistosomiasis through the regulation of cytokines, affecting the immune response and immune pathology [19]. To test whether the CTL-PDDV-induced $\mathrm{CD}^{+} \mathrm{T}$ cells were able to improve the immune 


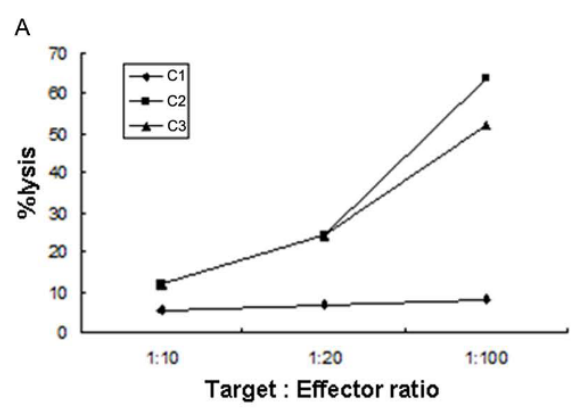

C

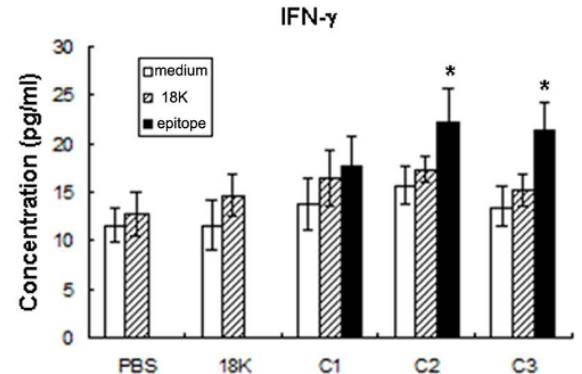

B

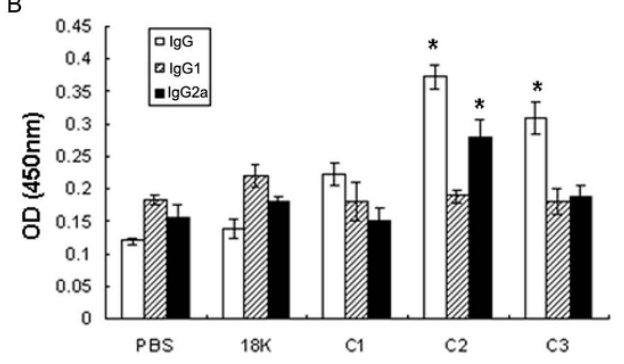

D

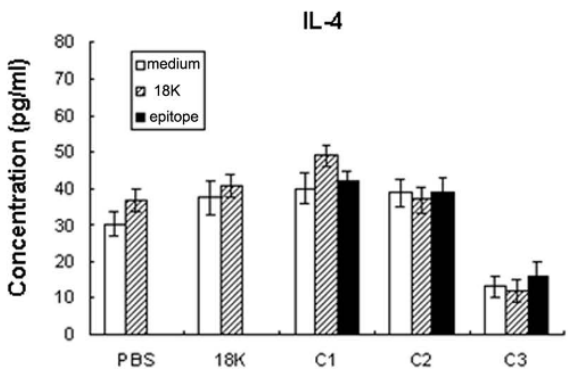

Figure 1 CTL-PDDVs induced the cytotoxicity effect and produced antibody. (A) Effect of C-PDDV vaccination on cytotoxicity. Seven days after the last C-PDDV, 18K-PDDV, or PBS immunization epitope-specific cytotoxic activity was measured by incubating murine spleen effector cells or p815 target cells with either C1-, C2-, or C3-18K fusion peptides, 18K control peptide, or medium only, then mixed cells at E:T rations ranging from 1:10 to 1:100. The CTL activity of the cells was tested using $\mathrm{Na}_{2}\left[{ }^{51} \mathrm{Cr}\right] \mathrm{O}_{4}$ assay. Data are expressed as the mean \pm SD $(n=6$ per group) of 18 mice from three independent experiments performed in triplicate wells. (B) Serum antibody subtype profile following C-PDDV vaccination. Whole $\lg G, \operatorname{lgG} 1$, and $\lg G 2$ a responses to $S W A(0.1 \mathrm{mg} / \mathrm{ml})$ following vaccination with C-PDDV formulations, or controls were measured by ELISA. Data are expressed as the mean \pm SD ( $n=6$ per group) of 18 mice from three independent experiments performed in triplicate wells. ${ }^{*} P<0.05$ and ${ }^{*} P<0.01$, compared to the 18K-PDDV and PBS groups. (C-D) Cytokine profile analysis following C-PDDV vaccination. IFN- $\gamma(C)$ and IL-4 (D) production of splenocytes harvested from every vaccination group were determined by culturing in triplicate. In 96-well plates, $10^{6} \mathrm{cells} /$ well were cultured for $48 \mathrm{~h}$ in $200 \mu \mathrm{l}$ of media in the presence of C1-, C2-, C3-18K fusion peptide (10 $\left.\mu \mathrm{g} / \mathrm{ml}\right), 18 \mathrm{~K}(10$ $\mu \mathrm{g} / \mathrm{ml}$ ), or media alone. Supernatants were collected after $48 \mathrm{~h}$ of culture for cytokine detection. Bars show the mean \pm SD ( $n=6$ per group) of 18 mice from three independent experiments performed in triplicate wells.

response induced by $\mathrm{T}$ - and $\mathrm{B}-\mathrm{PDDV}$, and to further investigate whether the multicomponent PDDV formulations could result in better immune effection, mice were immunized with multicomponent PDDV preparations containing three different types of single PDDVs at a 1:1:1 ratio, and the levels of cytokines in culture supernatants and antibodies in sera of vaccinated mice were measured. C1 and T2-PDDV were not selected for further study because of their poor immune responses in above studies, only C2, C3, T3, and B-PDDVs were used. As shown in Figure 4A, mice vaccinated with equal concentrations of different PDDV formulations revealed that IFN- $\gamma$ production was statistically elevated in the C3-T3-B2 and C3-T3-B3-vaccinated groups following restimulation in vitro with SWA containing Sj22.6, Sj62, and Sj97 proteins (Figure 4A). In contrast, IL-4 levels were statistically elevated in mice vaccinated with C2-T3-B2 following SWA in vitro restimulation (Figure 4B). Compared to the both 18K-PDDV and PBS control groups, only $\mathrm{C} 2-\mathrm{T} 3-\mathrm{B} 2$ and $\mathrm{C} 3-\mathrm{T} 3-\mathrm{B} 2$ groups induced significantly increased IgG responses (Figure 4C).
However, only C2-T3-B2-immunized mice developed a significant IgG1 response (Figure 4D), with IgG2a antibody only elicited in the C3-T3-B2 group (Figure 4E). These data suggest that different epitope combinations favore different cytokine and antibody subclass production profiles, highlighting the importance of selecting the appropriate antigen combination for the induction of the immune responses most likely to elicit protective immunity.

\section{PDDV cocktails did not improve the resistance to $S$. japonicum infection}

The protective effect conferred by the different PDDV or PDDV multicomponent formulations was determined by quantifying worm and egg (liver) burdens in the respective vaccination/infection groups (Table 2). Consistent with results described previously by our group $[13,14]$, T3- and B3-PDDV vaccinations induced significant reductions in worm and egg burdens in this experiment. Vaccination with T3-PDDV resulted in a $35.80 \%$ worm burden reduction and a $51.60 \%$ egg (liver) 

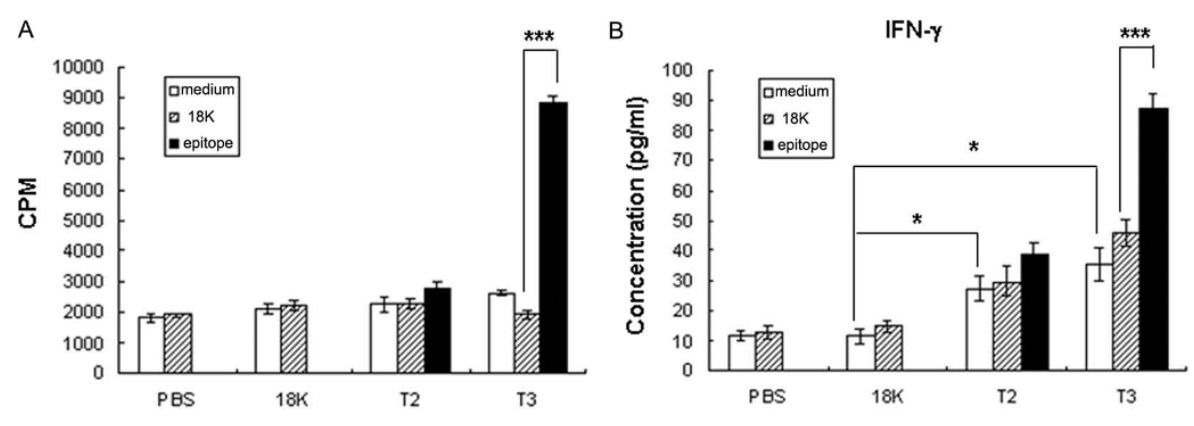

C

IL-4

D
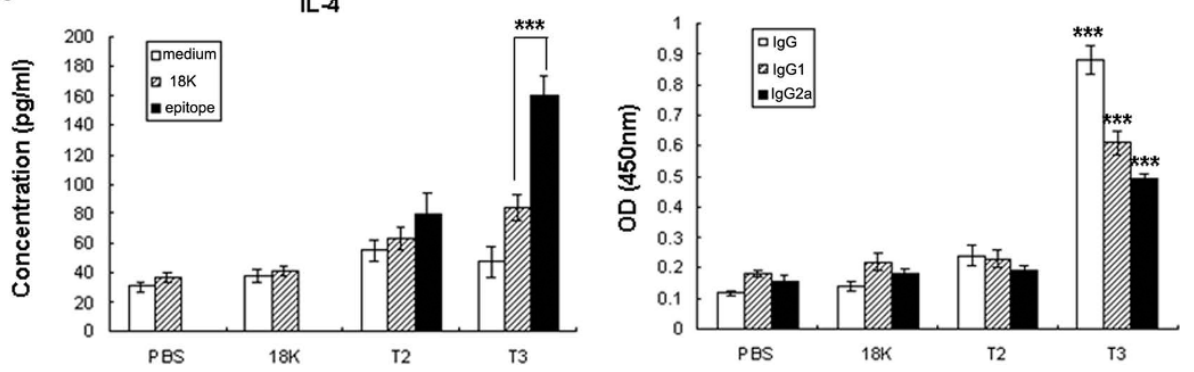

Figure 2 T3-PDDV induced both cellular and humoral immune responses. (A) T-PDDV induced cellular immunity. Seven days after the last immunization with T-PDDVs, 18K-PDDV, or PBS, splenocytes were harvested and antigen-specific proliferation was measured. Splenocytes $(2 \times$ $10^{5} /$ well) from each mouse were incubated in triplicate for three days in $200 \mu \mathrm{l}$ in 96-well plates in the presence of either the T2-18K, T3-18K, or $18 \mathrm{~K}$ peptides $(10 \mu \mathrm{g} / \mathrm{ml})$, or media alone. To each well $0.5 \mu \mathrm{Ci}\left[{ }^{3} \mathrm{H}\right]$ thymidine was added $16 \mathrm{~h}$ before the end of the incubation period. Data are expressed as the mean $\pm S D\left(n=6\right.$ per group) of 18 mice from three independent experiments performed in triplicate wells. ${ }^{* * *} P<0.001$. (B-C) Cytokine production following T2- or T3-PDDV vaccinations. IFN- $\gamma$ (B) and IL-4 (C) production was measured in splenocytes harvested and cultured from the respective vaccination groups for $48 \mathrm{~h}$. Bars show the mean \pm SD ( $n=6$ per group) of 18 mice from three independent experiments performed in triplicate wells. ${ }^{*} P<0.05$; ${ }^{* *} P<0.001$. (D) $\operatorname{lgG}, \lg \mathrm{G} 1$, and $\lg \mathrm{G} 2 \mathrm{a}$ responses in immunized mice. Antibody responses to SWA $(0.1 \mathrm{mg} / \mathrm{ml})$ were determined by ELISA. ${ }^{* *} P<0.001$, compared with $18 \mathrm{~K}$-PDDV and PBS groups. Data are expressed as the mean \pm SD ( $n=6$ per group) of 18 mice from three independent experiments performed in triplicate wells.

reduction compared to $18 \mathrm{~K}-\mathrm{PDDV}$-vaccinated controls. Similarly, vaccination with B3-PDDV resulted in a $19.10 \%$ worm reduction and a $29.20 \%$ egg (liver) reduction compared to the 18K-PDDV-vaccinated controls. Meanwhile, only mice immunized with C3-T3-B2 were partially protected (more than $10 \%$ protection in both worm and egg reductions compared to controls). However, the data suggests that multicomponent formulations (using the epitopes described) failed to improve the resistance to $S$. japonicum infection compared to single epitope (T3 or B3) PDDV vaccination.

\section{Histopathology of egg granulomas in mice livers}

Based on the protection results described above, we selected the vaccination groups with highest egg reductions for mice liver histologic examination. Compared to both control groups, the average number of egg granulomas in 10 random fields after the challenge infection was significantly decreased in the livers of mice immunized mice with T3PDDV or with the C3-T3-B2 PDDV preparation (Figure 5A). In addition, the mean-area of non-confluent granulomas in these livers was statistically smaller in T3PDDV-vaccinated mice. These data suggest that immunization with the T3-PDDV or C3-T3-B2 PDDV reduced the number and/or size of egg granulomas (Figure $5 B)$.

\section{Discussion}

The development of vaccines for complex parasites such as schistosomes is a great challenge. Vaccination with radiation-attenuated cercariae induces significant levels of resistance to schistosome challenge and suggests the fact that vaccination induced both $\mathrm{B}$ and $\mathrm{T}$ cell responses are critical, and combination of different antigens may be an efficient strategy to improve the immunoprotection against schistosome infection. In this study, different schistosome vaccine candidates (alone or mixed) that stimulated either $\mathrm{B}$ or $\mathrm{T}$ cell immunity were tested in a mouse model of disease. Results showed that combining different antigens in fact did not result in a more effective vaccine formulation when compared to each component administered individually, suggesting that mixed antigens may not be necessary for protection against schistosome infections and that immune interference resulting from the inoculation with multiple 

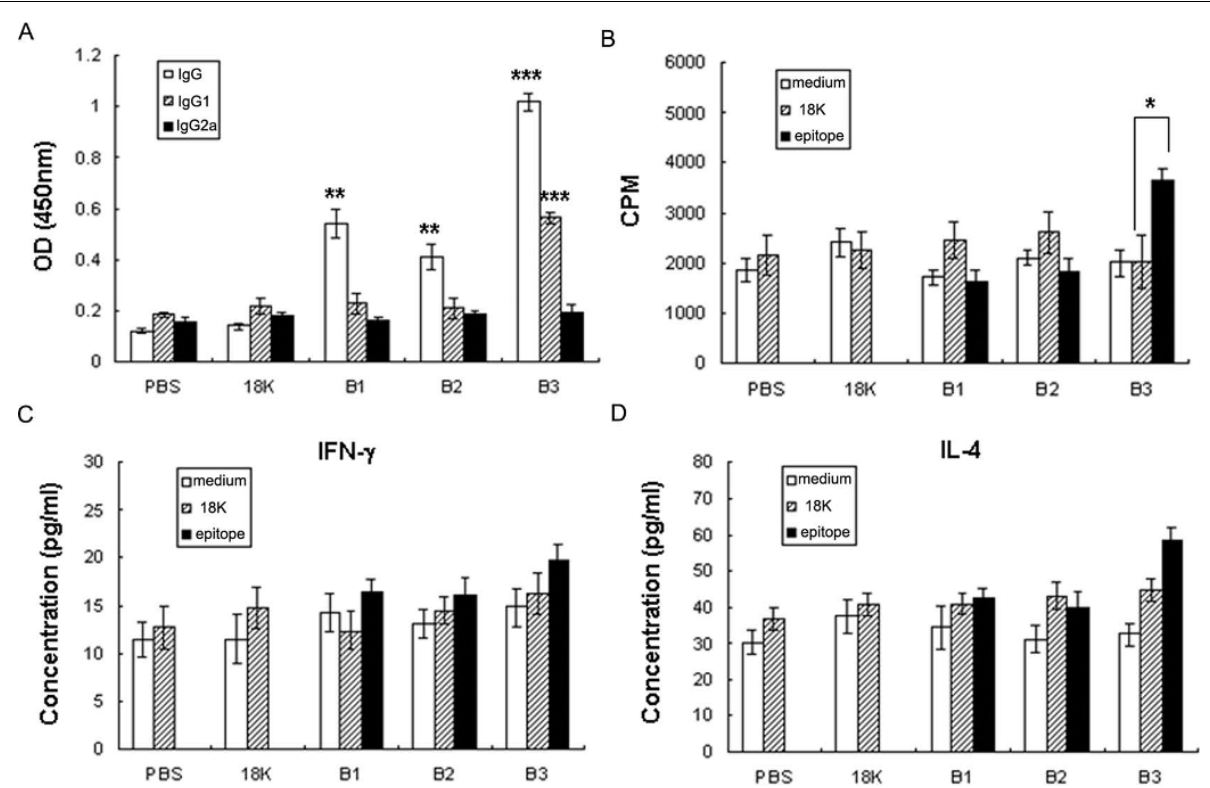

Figure 3 B3-PDDV induced the highest antibody response. (A) Analysis of B-PDDV-induced antibody responses. Seven days after the last immunization with B-PDDVs, 18K-PDDV, or PBS, mouse whole lgG, lgG1, and lgG2a antibody responses to SWA (0.1 mg/ml) were analyzed by ELISA. Data are expressed as the mean \pm SD ( $n=6$ per group) of 18 mice from three independent experiments performed in triplicate wells. ** $P<0.01$ and ${ }^{* * *} P<0.001$, compared to the $18 \mathrm{~K}$-PDDV and PBS groups. (B) Splenocyte proliferation assay. Splenocytes $\left(2 \times 10^{5} / \mathrm{well}\right)$ from each mouse were incubated in triplicate wells for three days in $200 \mu \mathrm{l}$ of media in 96-well plates in the presence of B1-, B2-, B3-18K fusion peptide, or $18 \mathrm{~K}(10 \mathrm{\mu g} / \mathrm{ml})$ peptides (or media alone). Proliferation was determined by measuring $\left[{ }^{3} \mathrm{H}\right]$ thymidine incorporation for the last $16 \mathrm{~h}$ of the experiment. Data are expressed as the mean $\pm S D\left(n=6\right.$ per group) of 18 mice from three independent experiments. ${ }^{*} P<0.05$. (C-D) Cytokine production analysis. Supernatants were collected after $48 \mathrm{~h}$ of culture and examined for IFN- $\gamma$ (C) or IL-4 (D). Bars show the mean \pm SD $(n=6$ per group) of 18 mice from three independent experiments performed in triplicate wells.

antigens is one mechanism responsible for the unexpected lack of increased protection.

Many years devoted to studying the interactions between schistosome infection and the resulting immune responses by hosts has led to the identification of mechanisms believed to play a critical role in protective immunity. Studies have shown that protection elicited by vaccination is not dependent on one immune mechanism but is multifactorial, involving both cellular and humoral elements and can be affected by the host's genetic background and the vaccine regimen $[35,36]$. Therefore, to improve antischistosome immunity and protection against infection conferred by respective vaccine formulations, various strategies including multiple antigenic peptides (MAPs), i.e. sequential arrangement of epitopes into a single polypeptide and multicomponent formulations, have been tested $[17,23,24]$. These vaccination modalities have been tested in animal models and some formulations have proved successful $[37,38]$, suggesting that multicomponent formulations can be used to develop effective anti-schistosome vaccines. Recently, we demonstrated that vaccination with PDDV based on a T cell-epitope (P5, in this study named T3) derived from the $\mathrm{Sj} 22.6$ tegument antigen or a B cellepitope (B3) derived from the Sj62 myosin sequence all induced partial protection against $S$. japonicum challenge in mice $[13,14]$. In this study we predicted and selected six additional peptide epitopes derived from full-length $\mathrm{Sj} 22.6$, Sj62, and Sj97 antigens shown to have the potential of eliciting protective immunity in various other studies $[6,13,14,39-42]$. The experiments were aimed at improving the immunoreactivity and protective efficacy of the peptide-based approach by comparing immune responses following vaccinations with either single or multicomponent formulations in mice subsequently infected with $S$. japonicum. Results from mice vaccinated with Tc-, Th-, or BPDDV single-epitope formulations showed that not every single-epitope PDDV elicits corresponding cytotoxic, T helper or antibody responses. This finding suggests that at present, computer assisted epitope prediction is not a very effective way of generating epitopes and experimental validation must remain an early step in any vaccine study.

In contrast to the immune response induced by single PDDVs, cytokine release and antibody production induced by multicomponent PDDV formulations showed varied immune response profiles and variability in protective immunity conferred following vaccination with multicomponent formulations was not always more effective than that observed in mice immunized with single component PDDV preparations. For example, among multicomponent PDDV formulations, only C2- 

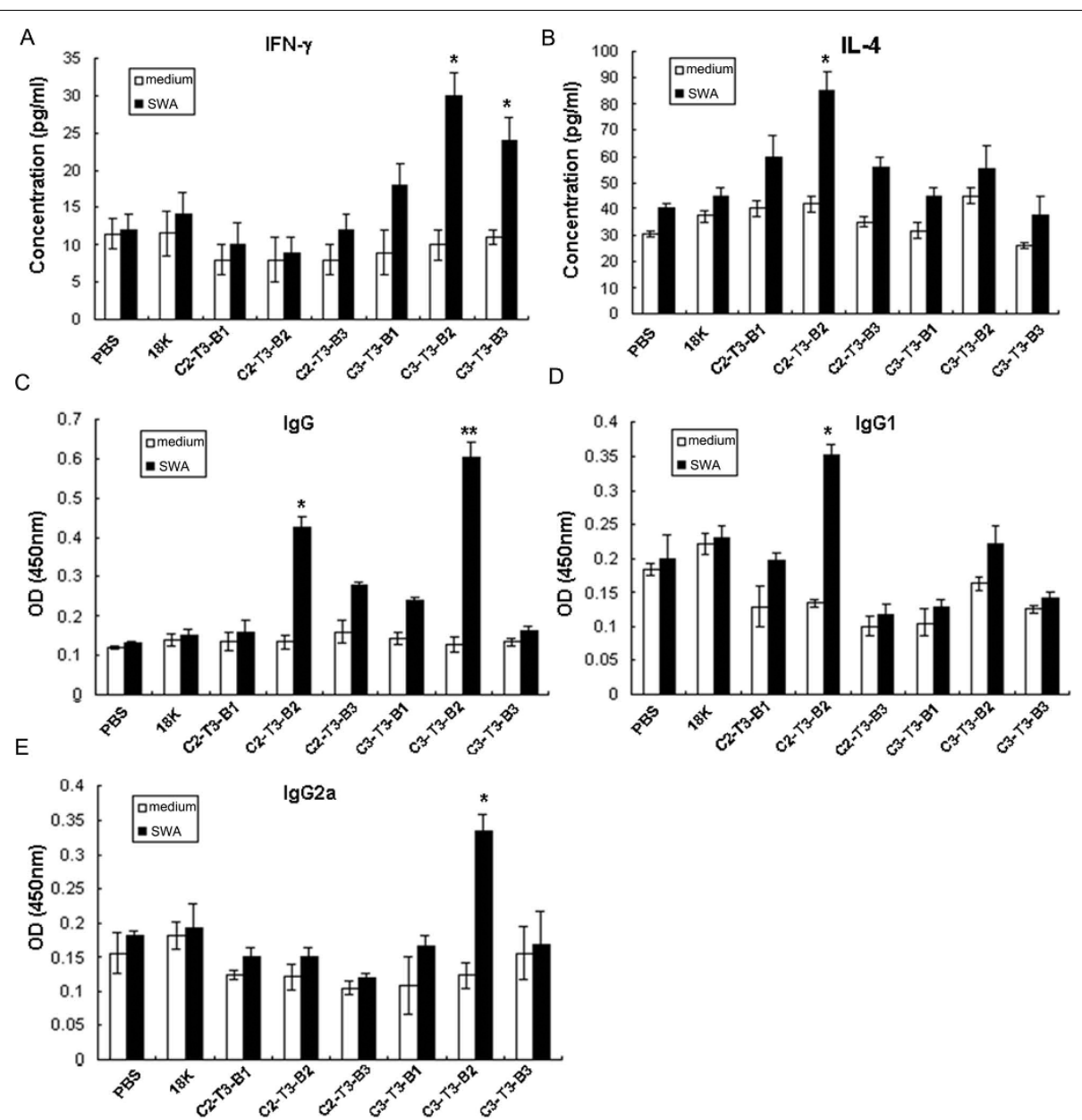

Figure 4 Cytokines and antibodies responses in mice vaccinated with CTL-, T-, and B-PDDV cocktails. (A-B) Cytokine responses following vaccination with C-, T- and B-PDDV multicomponent formulations. Seven days after the last immunization with either multicomponent PDDV formulations, 18K-PDDV, or PBS, splenocyte production of IFN- $\gamma$ (A) and IL-4 (B) from each vaccine group was assessed. Splenocytes from each mouse were cultured $\left(10^{6} /\right.$ well) in triplicate for $48 \mathrm{~h}$ in the presence or absence of SWA $(50 \mathrm{\mu g} / \mathrm{ml})$. Supernatants were collected after $48 \mathrm{~h}$ and IFN- $\gamma$ and IL-4 production was assessed. The data are expressed as the mean \pm SD ( $n=6$ per group) of 12 mice from two independent experiments performed in triplicate wells. (C-E) Antibody responses following multicomponent vaccinations. IgG (C), IgG1 (D), and IgG2a (E) responses to SWA in immunized mice were determined by ELISA. Data are expressed as the mean \pm SD ( $n=6$ per group) of 12 mice from two independent experiments performed in triplicate wells. ${ }^{*} P<0.05$ and ${ }^{* * *} P<0.001$, compared to the $18 \mathrm{~K}$-PDDV and PBS groups.

T3-B2, C3-T3-B2, and C3-T3-B3-immunized mice induced partial protection in reducing worm or egg burdens, but all multicomponent PDDV formulations containing T3- or B3-PDDV were not more effective in reducing worm and egg burdens nor did multicomponent formulations elicit significant changes in cytokine or antibody production, when compared to mice immunized with single formulations of T3- or B3-PDDV. These data suggest that T3- or B3-PDDV appeared to elicit a protective response against the parasite, but other epitopes or multicomponent formulations failed to induce an adequate immune response to improve the protection. Furthermore, these results also indicate that combinations of different types of antigenic epitopes may result in immune interference resulting in the development of inefficient immune responses incapable of conferring protective immunity $[43,44]$. Others have shown that multicomponent vaccines can be more immunogenic and produce significant anti-parasite activity [45-47]. Similarly, DNA vaccines containing multiple antigens also contributed to improved protective responses against Schistosoma. For example, using a DNA vaccine encoding Sj62, Sj28, Sj23, and Sj14-3-3 induced significant Th1type cellular responses and conferred partial protection against S. japonicum infection [48]. However, others have also reported different results in relation to multicomponent formulations e.g., a multicomponent vaccine based on antigenic epitopes derived from SmTPI, Sm28, Sm97, Sm23, and Smcalpain of S. mansoni did not elicit a response capable of parasite killing in vivo [49]. Several 
Table 2 Worm and egg burdens following vaccination

\begin{tabular}{|c|c|c|c|c|c|c|}
\hline \multirow{2}{*}{$\begin{array}{l}\text { Vaccination } \\
\text { Regimen }\end{array}$} & \multirow{2}{*}{$\begin{array}{l}\text { Mean worm } \\
\text { count } \pm \text { SD }\end{array}$} & \multirow{2}{*}{$\begin{array}{l}\text { Mean liver egg } \\
\text { count } \pm \text { SD }\end{array}$} & \multicolumn{2}{|c|}{ Worm reduction rate (\%) } & \multicolumn{2}{|c|}{ Liver egg reduction rate(\%) } \\
\hline & & & $\begin{array}{l}\text { Compared to the } \\
\text { PBS group }\end{array}$ & $\begin{array}{l}\text { Compared to the } \\
18 \mathrm{~K} \text { group }\end{array}$ & $\begin{array}{l}\text { Compared to the } \\
\text { PBS group }\end{array}$ & $\begin{array}{l}\text { Compared to the } \\
18 \mathrm{~K} \text { group }\end{array}$ \\
\hline $\mathrm{C} 2$ & $31.33 \pm 6.66$ & $20900.9 \pm 1899.84$ & -31.3 & -34.5 & 10.08 & 3.7 \\
\hline C3 & $24.50 \pm 4.23$ & $18558.54 \pm 2120.31$ & -2.5 & -5.2 & $20.16^{*}$ & 14.5 \\
\hline T3 & $14.50 \pm 8.39$ & $10270.27 \pm 4357.82$ & $39.33^{* *}$ & $35.80^{* *}$ & $55.81^{* *}$ & $51.60^{* *}$ \\
\hline B1 & $23.71 \pm 7.18$ & $20308.88 \pm 3154.43$ & 0.78 & 0 & 12.62 & 6.5 \\
\hline B2 & $20.40 \pm 6.47$ & $21513.51 \pm 4128.92$ & 14.64 & 12.4 & 7.44 & 0.9 \\
\hline B3 & $18.86 \pm 3.35$ & $15366.78 \pm 2371.41$ & $22.70^{*}$ & $19.10^{*}$ & $34.81^{* *}$ & $29.20^{*}$ \\
\hline C2-T3-B1 & $24.80 \pm 6.98$ & $19243.24 \pm 2172.86$ & -3.8 & -6.4 & 17.21 & 11.4 \\
\hline C2-T3-B2 & $18.75 \pm 1.73$ & $20000.0 \pm 2167.85$ & $21.55^{*}$ & $19.5^{*}$ & 13.95 & 7.9 \\
\hline C2-T3-B3 & $22.57 \pm 7.14$ & $22162.16 \pm 4496.31$ & 5.56 & 3.1 & -2.1 & 4.7 \\
\hline C3-T3-B1 & $25.75 \pm 6.70$ & $18648.65 \pm 4105.15$ & -7.7 & -10.5 & $19.77^{*}$ & 14.1 \\
\hline C3-T3-B2 & $20.00 \pm 6.40$ & $12540.54 \pm 4658.24$ & 16.32 & 14.2 & $46.05^{* *}$ & $42.2^{* *}$ \\
\hline C3-T3-B3 & $21.33 \pm 2.83$ & $15855.84 \pm 4944.18$ & 10.74 & 8.4 & $31.78^{*}$ & $27.0^{*}$ \\
\hline $18 \mathrm{~K}$ & $23.33 \pm 6.41$ & $21711.70 \pm 3937.61$ & / & / & / & / \\
\hline PBS & $23.88 \pm 7.91$ & $23243.24 \pm 4784.20$ & / & / & / & / \\
\hline
\end{tabular}

The mean worm/liver egg burdens were calculated using results from sixteen mice from two independent experiments $(\mathrm{n}=8$ ). Percent protection in the two independent experiments was calculated by comparing their results with the results obtained from the 18K-PDDV and PBS groups. Results are expressed as means \pm standard errors. ${ }^{*} P<0.05 ;{ }^{*} P<0.01$, compared to the worm/liver egg burdens of the $18 \mathrm{~K}-\mathrm{PDDV}$ and PBS vaccination groups.

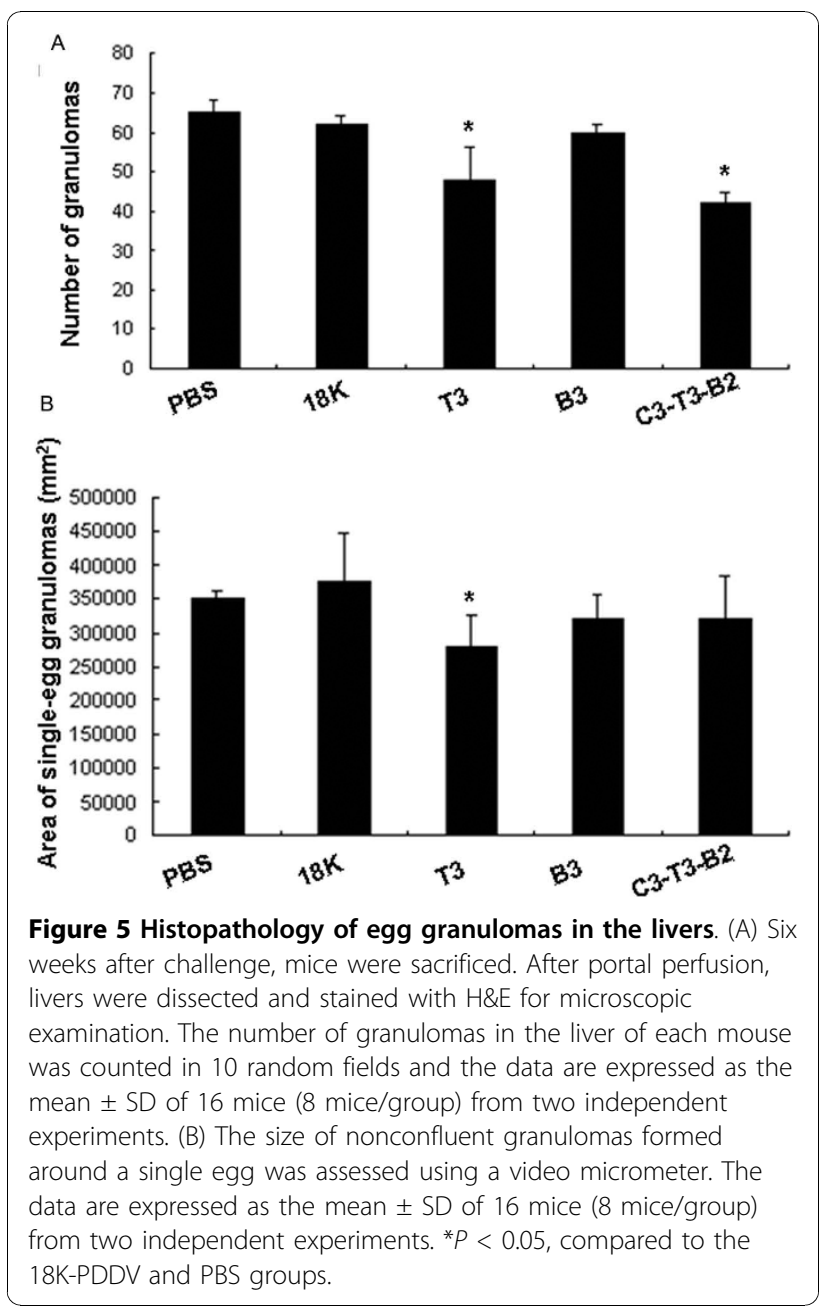

studies have addressed the properties of an epitope-specific regulatory system $[50,51]$ that selectively controls immune response (such as IgG antibody production) to the individual determinants on a complex antigen. These regulatory responses are commonly believed to regulate the amount, affinity, and isotype composition of antibody responses to individual epitopes on complex antigens by interference [51].

In this study, even though we failed to demonstrate improved protective efficacy using a multiple component-based vaccine strategy, we still derived insights regarding effective design of $S$. japonicum vaccines in two ways. First, predicting epitopes with software alone is not sufficient. A combination of epitope prediction and experimental screening is needed. Second, multiple epitope vaccines capable of inducing protective antibody and cell mediated immune responses against different schistosomal developmental stages theoretically may be more effective, however, the multivalent vaccine construct must be well designed to not suffer the effects of epitope interference.

\section{Conclusion}

In conclusion, we have developed single PDDVs and multicomponent PDDV anti-S. japonicum formulations. Our experiments demonstrate that mice immunized with single PDDV formulations were partially protected against S. japonicum infection and that mice vaccinated with multicomponent formulations were not necessarily better protected against $S$. japonicum challenge. These data suggest that immune interference may account for 
the inefficiency of the multicomponent formulations and that care must be taken in the selection of epitopes identified for vaccine preparations containing multiple epitopes.

\section{Methods}

\section{Animal studies and antigen preparation}

Six-week-old C57BL/6 female mice were provided by the Center of Experimental Animals (Nanjing University, Nanjing, PR China). Oncomelania hupensis harboring $S$. japonicum cercariae (Chinese mainland snail strain) were purchased from the Jiangsu Institute of Parasitic Diseases (Wuxi, PR China). All animal experiments were performed in accordance with the Chinese laws for animal protection and with permission from the Institutional Review Board. Soluble schistosome worm antigen (SWA) was prepared as previously described [52].

\section{Identification of antigenic epitopes}

Selection of B-cell epitopes was based on predictions made by the Immune Epitope Database and Analysis Resource (IEDB; http://epitope2.immuneepitope.org/ home.do) [53] and ProtScale http://www.expasy.org/cgibin/protscale.pl[14,54]. All putative T-cell epitopes were predicted using GUATIF, TEPITOPE and ANTHIWHIN software $[13,55]$. Briefly, the amino acid sequences for Sj22.6 (GenBank Accession No: AAC67308), Sj62 (GenBank Accession No: AAC82332), and Sj97 (GenBank Accession No: Q05870) were analyzed by software designed to predict the epitopes and candidate peptides most likely to elicit Tc-, Th-, or Bcell responses selected based on their respective prediction scores. The 8 selected epitopes containing an 18 Lys (18K) N-terminal tail (epitope-18K fusion peptides) were synthesized and an $18 \mathrm{~K}$ control peptide was also synthesized and purified (Invitrogen, Shanghai, PR China). The purity of the peptides determined by mass spectrometry was $>99 \%$. The DNA sequences encoding each of the 8 identified epitopes were synthesized and purified based on the published S. japonicum DNA sequences, respectively, for Sj22.6 (GenBank Accession No: AF030404), Sj62 (GenBank Accession No: No. AF039187), and Sj97 (GenBank Accession No: EU488866) (Invitrogen). SalI and EcoRI restriction sites were included in the primer sequences for cloning purposes.

\section{Preparation of PDDVs}

PDDVs encoding the eight antigenic epitopes were prepared and confirmed as described previously [13,14]. The diagram of PDDV preparation was shown in Additional file 1. Briefly, the recombinant expression plasmid pUMVC1-mGM-CSF (a gift from Professor Yuzhang $\mathrm{Wu}$, Institute of Immunology of the Third Military
Medical University, Chongqing, PR China) was 4423 base pairs (bp) long and contained the cytomegalovirus (CMV) promoter and the mouse GM-CSF gene. The two complementary single stranded oligonucleotides encoding each respective epitope were annealed and inserted into the pUMVC1-mGM-CSF vector and the resulting plasmids transformed into Escherichia coli DH5 $\alpha$ grown in Luria Bertani (LB) broth. The recombinant plasmid DNAs were purified using the QIAGEN Endofree Plasmid Maxi Kit (QIAGEN, Hilden, Germany). Plasmid preparations were resuspended in $\mathrm{ddH}_{2} \mathrm{O}$ to a final concentration of $1.5-2.0 \mathrm{mg} / \mathrm{ml}$. Agarose gel electrophoresis confirmed that the plasmid preparations were not contaminated with bacterial genomic DNA or RNA. Preparation of the PDDVs was performed by titrating peptide into a solution of DNA containing $10 \mathrm{mM}$ HEPES and $150 \mathrm{mM} \mathrm{NaCl}$ as described previously $[13,14]$. The cationic poly-lysine in $18 \mathrm{~K}$ control peptide or epitope-18K fusion peptide was bound to the anionic plasmid DNA (containing the sequence of corresponding epitope) through electrostatic interactions and the peptide-DNA complex (PDDV) was condensed into nanometric pseudotype virus-like particles. Each PDDV was adjusted with phosphate buffered saline (PBS, pH 7.4) to $100 \mu \mathrm{l}$ containing of $28 \mu \mathrm{g}$ of peptide and $10 \mu \mathrm{g}$ of plasmid. The PDDV containing either the control $18 \mathrm{~K}$ or the Tc-, Th-, or B-cell epitope-18K fusion peptide were designated as $18 \mathrm{~K}-\mathrm{PDDV}, \mathrm{C}-\mathrm{PDDV}, \mathrm{T}-\mathrm{PDDV}$ or B-PDDV, respectively. The integrity of the PDDVs was confirmed using the DNA retardation assay, DNase I digestion assay and transmission electron microscopy as described previously $[13,14]$.

\section{Immunization and challenge infection}

For immune response characterization, three independent experiments were carried out. In each experiment, C57BL/6 mice (6 mice per group) were injected subcutaneously (s.c.) in the back with $100 \mu \mathrm{l}$ of PBS (control 1), 18K-PDDV (control 2), C-, T-, or B-PDDV per mouse, respectively. The immunization was repeated three times at 14-day intervals. One week after the final vaccination, mice were sacrificed for the characterization of cellular and humoral immune response.

For vaccination/challenge trial, two independent experiments were carried out. In each experiment, C57BL/6 mice were divided into fourteen groups consisting of 14 mice per group. Each mouse was injected subcutaneously (s.c.) in the back with $100 \mu \mathrm{l}$ of PBS (control 1), 18K-PDDV (control 2), C-, T-, B-PDDV, or multicomponent PDDV preparations, respectively. The multicomponent PDDV preparations were prepared by mixing the single PDDVs at a 1:1:1 ratio $(33.3 \mu \mathrm{l}$ each of C, T- and B-PDDVs, respectively) consisting of $28 \mu \mathrm{g}$ of peptides and $10 \mu \mathrm{g}$ of plasmids in total. The 
immunization was repeated three times at 14-day intervals. One week after the final vaccination, six mice from each group were sacrificed for the cytokine and antibody detection. Two weeks after the final vaccination, the remaining eight mice from each group were challenged percutaneously with $40 \pm 1 S$. japonicum cercariae. Six weeks later the mice were sacrificed and perfused to determine worm burdens and the liver egg burdens. Reductions in worms/liver egg burdens are expressed as a percentage of the burden recorded in the control groups.

\section{Cytotoxicity assay}

Cytotoxicity was determined by a $4 \mathrm{~h}{ }^{5 \mathrm{C}} \mathrm{Cr}$ release assay as described previously [56]. Briefly, spleen cells were harvested from PBS, C1-, C2-, C3-PDDV or 18K-PDDV immunized mice and resuspended at a concentration of 1 $\times 10^{6} / \mathrm{ml}$ in complete 1640 medium (containing $10 \% \mathrm{FCS}$, $100 \mathrm{U} / \mathrm{ml}$ penicillin, $100 \mu \mathrm{g} / \mathrm{ml}$ streptomycin) containing $10 \mu \mathrm{g} / \mathrm{ml} \mathrm{C1-,} \mathrm{C2-,} \mathrm{C3-18K} \mathrm{fusion} \mathrm{peptide,} \mathrm{18K} \mathrm{control}$ peptide or medium only. After a five-day incubation at $37^{\circ}$ $\mathrm{C}$, the cells were washed and used as effector cells and $5 \times$ $10^{6}$ p815 $\left(\mathrm{H}-2^{\mathrm{d}}\right)$ cells were labeled with $200 \mu \mathrm{Ci} \mathrm{Na}{ }^{2}\left[{ }^{51} \mathrm{Cr}\right]$ $\mathrm{O}_{4}$ for $1 \mathrm{~h}$. After thorough washing, labeled p815 cells were used as target cells and pulsed with $10 \mu \mathrm{g} / \mathrm{ml} \mathrm{C1-}$, C2-, C3-18K fusion peptide, $18 \mathrm{~K}$ control peptide or medium only for $2 \mathrm{~h}$ at $37^{\circ} \mathrm{C}$, washed and resuspended in complete RPMI 1640 at a concentration of $1 \times 10^{5} / \mathrm{ml}$. Effector cells were titrated by serial dilution in U-bottom 96-well plates at Effector/Target ratios of 100:1, 20:1, 10:1. $1 \times 10^{4}$ target cells were added, centrifuged for $30 \mathrm{~s}$ at $100 \times \mathrm{g}$ and the Effector-Target-cell mix incubated at $37^{\circ} \mathrm{C}, 5 \% \mathrm{CO}_{2}$, $90 \%$ humidity for $4 \mathrm{~h}$. After centrifugation at $250 \times \mathrm{g}$ for $10 \mathrm{~min}, 100 \mu \mathrm{l} /$ well supernatant from respective wells was removed and CPMs were measured with a gamma counter (Beckman, Fullerton, USA). The percent specific lysis was determined using the following equation: $100 \times[($ experimental release-spontaneous release)/(maximum releasespontaneous release)], with spontaneous release measured as the counts obtained from target cells incubated in medium alone, and maximum release determined by the counts obtained from target cells exposed to $1 \%$ Triton X-100.

\section{Enzyme-linked immunosorbent assay (ELISA)}

Serum samples were collected seven days after the last immunization. Standard ELISAs were performed using SWA as the antigen source $[39,52]$. Antibody detection in the sera of immunized mice was performed as previously described $[13,14]$. IFN- $\gamma$ and IL-4 levels in the supernatants of splenocytes stimulated by antigens from PBS, 18K-PDDV, C-, T-, B-PDDV, or multicomponent PDDV immunized mice were measured by ELISA using the eBioscience ELISA Ready-set-Go kit (eBioscience, San Diego, USA), according to the manufacturer's instructions.

\section{Splenocyte proliferation assay}

$\left[{ }^{3} \mathrm{H}\right]$ thymidine $\left({ }^{3} \mathrm{H}-\mathrm{TdR}\right)$ incorporation was used to measure splenocyte proliferation. Seven days after the last immunization, six mice from each group were sacrificed and splenocytes harvested. In 96-well plates, $2 \times$ $10^{5}$ cells per well were incubated for $72 \mathrm{~h}$ in $200 \mu \mathrm{l}$ of complete media in the presence of the respective epitope- $18 \mathrm{k}$ fusion peptides $(10 \mu \mathrm{g} / \mathrm{ml})$ or the $18 \mathrm{~K}$ control $(10 \mu \mathrm{g} / \mathrm{ml})$. After $56 \mathrm{~h}$ in culture, $\left[{ }^{3} \mathrm{H}\right]$ thymidine $(0.5$ $\mu \mathrm{Ci}$ ) (Amersham, Burkinghamshire, UK) was added to each well. At the end of the incubation period, the cells were harvested on filters and the incorporated $\left[{ }^{3} \mathrm{H}\right]$ thymidine counted.

\section{Histopathological examination}

After portal perfusion, livers were dissected and immediately fixed in $10 \%$ buffered formalin for morphometric analysis. Liver sections were embedded in paraffin and stained with hematoxylin and eosin (H\&E) for microscopic examination of granulomas at $4 \times$ (Olympus, Tokyo, Japan) following sectioning. The number of granulomas in the liver of each mouse was counted in 10 random fields. The size of nonconfluent granulomas formed around single eggs was assessed using a video micrometer (Olympus, Tokyo, Japan) in accordance with the manufacturer's instructions.

\section{Statistical analysis}

The statistical analysis was performed using SPSS version 10.1 (Statistical Package for Social Sciences, Chicago, IL statistical software). Statistical significance was determined by Student's $t$-test with $P<0.05$ considered statistically significant.

\section{List of abbreviations}

PDDV: peptide-DNA dual vaccine; s.c: subcutaneously; CTL: cytotoxic T lymphocyte S.japonicum: Schistosome japonicum; SWA: soluble schistosome worm antigen.

\section{Additional material}

Additional file 1: Schematic diagram of forming a PDDV. A cationic antigenic peptide containing 18 lysines (18K) and the antigenic epitope was designed and synthesized. An anionic plasmid containing the DNA sequence of the corresponding antigenic epitope sequence and mouse GM-CSF was constructed. The cationic peptides and corresponding anionic plasmids form virus-like particles through electrostatic interactions at an appropriate charge ratio of peptide and DNA.

\section{Acknowledgements}

We are grateful to Profs. Yuzhang Wu and Ying Wan (Institute of Immunology, Third Military Medical University, Chongqing, PR China) for their valuable assistances and critical reading of the manuscript. This work was supported by grants from the National Basic Research Program of China (973 Program) (No. 2007CB513106), the National Natural Science Foundation of China (No. 30872206), Major National Science \& 
Technology Special Program (NO: 2008ZX10004-011), and the grant 07KJA31023 from Jiangsu Province to Chuan Su.

\section{Author details}

${ }^{1}$ Department of Pathogen Biology and Immunology, Jiangsu Key Laboratory of Pathogen Biology, Department of Pharmacology, Nanjing Medical University, Nanjing, Jiangsu 210029, PR China. ${ }^{2}$ Central Laboratory of the Affiliated People's Hospital, Jiangsu University, Zhenjiang, Jiangsu 212002, PR China. ${ }^{3}$ Keck School of Medicine, University of Southern California, 1975 Zonal Avenue, KAM 100B, Los Angeles, CA 90089, USA

\section{Authors' contributions}

XFW designed and performed the study, managed, analyzed, and interpreted the data, and prepared the manuscript; LZ designed the study, facilitated and assisted the study implementation; YC, JH, SZ and XYW assisted in the design and study implementation and/or revised the manuscript; LH, FL and CW assisted in the design of the study, data analysis; CS designed the study, supervised the study implementation and revised the manuscript. All authors read and approved the final manuscript.

\section{Competing interests}

The authors declare that they have no financial, professional or personal competing interests related to this article. The funding agencies played no role in the design or implementation of the study, analysis or interpretation of the data, or the preparation and submission of the manuscript.

Received: 26 August 2010 Accepted: 19 November 2010 Published: 19 November 2010

\section{References}

1. Hotez PJ, Brindley PJ, Bethony JM, King CH, Pearce EJ, Jacobson J: Helminth infections: the great neglected tropical diseases. J Clin Invest 2008, 118:1311-1321.

2. King $\mathrm{CH}$ : Toward the elimination of schistosomiasis. N Engl J Med 2009, 360:106-109.

3. Doenhoff MJ, Cioli D, Utzinger J: Praziquantel: mechanisms of action, resistance and new derivatives for schistosomiasis. Curr Opin Infect Dis 2008, 21:659-667.

4. Fenwick A, Webster JP: Schistosomiasis: challenges for control, treatment and drug resistance. Curr Opin Infect Dis 2006, 19:577-582.

5. Balen J, Zhao ZY, Williams GM, McManus DP, Raso G, Utzinger J, Zhou J, Li YS: Prevalence, intensity and associated morbidity of Schistosoma japonicum infection in the Dongting Lake region, China. Bull World Health Organ 2007, 85:519-526.

6. McManus DP, Loukas A: Current status of vaccines for schistosomiasis. Clin Microbiol Rev 2008, 21:225-242.

7. Bergquist NR, Leonardo LR, Mitchell GF: Vaccine-linked chemotherapy: can schistosomiasis control benefit from an integrated approach? Trends Parasitol 2005, 21:112-117.

8. Hotez PJ, Bethony JM, Oliveira SC, Brindley PJ, Loukas A: Multivalent anthelminthic vaccine to prevent hookworm and schistosomiasis. Expert Rev Vaccines 2008, 7:745-752.

9. Abath FG, Montenegro SM, Gomes YM: Vaccines against human parasitic diseases: an overview. Acta Trop 1998, 71:237-254.

10. Coulson PS: The radiation-attenuated vaccine against schistosomes in animal models: paradigm for a human vaccine? Adv Parasitol 1997, 39:271-336.

11. Loukas A, Tran M, Pearson MS: Schistosome membrane proteins as vaccines. Int J Parasitol 2007, 37:257-263.

12. Ohta N, Kumagai T, Maruyama H, Yoshida A, He Y, Zhang R: Research on calpain of Schistosoma japonicum as a vaccine candidate. Parasitol Int 2004, 53:175-181.

13. Zhang L, Yang Y, Yang X, Zhao J, Yang J, Liu F, Zhang Z, Wu G, Su C: T cell epitope-based peptide-DNA dual vaccine induces protective immunity against Schistosoma japonicum infection in C57BL/6J mice. Microbes Infect 2008, 10:251-259.

14. Zhang L, Yang X, Yang Y, Zhao J, Yang J, Liu F, Zhang Z, Wu G, Su C: Characterization of a partially protective B-cell epitope within the 62 kDa antigen of Schistosoma japonicum. Acta Biochim Biophys Sin (Shanghai) 2007, 39:770-778.
15. Becker MM, Kalinna BH, Yang W, Harrop SA, Scott JC, Waine GJ, Kurtis JD, McManus DP: Gene cloning and complete nucleotide sequence of philippine Schistosoma japonicum paramyosin. Acta Trop 1995, 59:143-147.

16. El Ridi R, Shoemaker CB, Farouk F, El Sherif NH, Afifi A: Human T- and Bcell responses to Schistosoma mansoni recombinant glyceraldehyde 3phosphate dehydrogenase correlate with resistance to reinfection with S. mansoni or Schistosoma haematobium after chemotherapy. Infect Immun 2001, 69:237-244

17. Reynolds SR, Dahl CE, Harn DA: T and B epitope determination and analysis of multiple antigenic peptides for the Schistosoma mansoni experimental vaccine triose-phosphate isomerase. J Immunol 1994, 152:193-200.

18. Arnon R, Tarrab-Hazdai R, Steward M: A mimotope peptide-based vaccine against Schistosoma mansoni: synthesis and characterization. Immunology 2000, 101:555-562.

19. Pedras-Vasconcelos JA, Pearce EJ: Type 1 CD8+ T cell responses during infection with the helminth Schistosoma mansoni. J Immunol 1996, 157:3046-3053

20. Pancre V, Wolowczuk I, Guerret S, Copin MC, Delanoye A, Capron A Auriault C: Protective effect of $r S m 28 G S T$-specific T cells in schistosomiasis: role of gamma interferon. Infect Immun 1994, 62:3723-3730

21. Pancre V, Delacre M, Herno J, Auriault C: Schistosomal egg antigenresponsive CD8 T-cell population in Schistosoma mansoni-infected BALB/ c mice. Immunology 1999, 98:525-534.

22. Pancre V, Gras-Masse H, Delanoye A, Herno J, Capron A, Auriault C: Induction of cytotoxic T-cell activity by the protective antigen of Schistosoma mansoni Sm28GST or its derived C-terminal lipopeptide. Scand J Immunol 1996, 44:485-492.

23. Reis EA, Mauadi Carmo TA, Athanazio R, Reis MG, Harn DA Jr: Schistosoma mansoni triose phosphate isomerase peptide MAP4 is able to trigger naive donor immune response towards a type- 1 cytokine profile. Scand J Immunol 2008, 68:169-176.

24. El Ridi R, Mahrous A, Afifi A, Montash M, Velek J, Jezek J: Human and murine humoral immune recognition of multiple peptides from Schistosoma mansoni glyceraldehyde 3-P dehydrogenase is associated with resistance to Schistosomiasis. Scand J Immunol 2001, 54:477-485.

25. Otvos $L \mathrm{Jr}$ : Synthesis of a multivalent, multiepitope vaccine construct. Methods Mol Biol 2008, 494:263-273.

26. Patarroyo ME, Cifuentes $G$, Rodriguez R: Structural characterisation of sporozoite components for a multistage, multi-epitope, anti-malarial vaccine. Int J Biochem Cell Biol 2008, 40:543-557.

27. Matthews LJ, Davis R, Smith GP: Immunogenically fit subunit vaccine components via epitope discovery from natural peptide libraries. $J$ Immunol 2002, 169:837-846.

28. Patarroyo ME, Cifuentes G, Bermudez A, Patarroyo MA: Strategies for developing multi-epitope, subunit-based, chemically-synthesized antimalarial vaccines. J Cell Mol Med 2007.

29. Amexis $G$, Young NS: Multiple antigenic peptides as vaccine platform for the induction of humoral responses against dengue-2 virus. Viral Immunol 2007, 20:657-663.

30. Zavala F, Tam JP, Barr PJ, Romero PJ, Ley V, Nussenzweig RS, Nussenzweig $V$ : Synthetic peptide vaccine confers protection against murine malaria. J Exp Med 1987, 166:1591-6.

31. Pathak A, Aggarwal A, Kurupati RK, Patnaik S, Swami A, Singh Y, Kumar $P$, Vyas SP, Gupta KC: Engineered polyallylamine nanoparticles for efficient in vitro transfection. Pharm Res 2007, 24:1427-1440.

32. Walsh M, Tangney M, O'Neill MJ, Larkin JO, Soden DM, McKenna SL, Darcy R, O'Sullivan GC, O'Driscoll CM: Evaluation of cellular uptake and gene transfer efficiency of pegylated poly-L-lysine compacted DNA implications for cancer gene therapy. Mol Pharm 2006, 3:644-653.

33. Liu HL, Wu YZ, Zhao JP, Ni B, Jia ZC, Zhou W, Zou LY: Effective elicitation of anti-tumor immunity by collocation of antigen with encoding gene in the same vaccine. Immunol Lett 2003, 89:167-173.

34. Wu YZ, Zhao JP, Wan Y, Jia ZC, Zhou W, Bian J, Ni B, Zou LY, Tang Y: Mimovirus: a novel form of vaccine that induces hepatitis $B$ virusspecific cytotoxic T-lymphocyte responses in vivo. J Virol 2002, 76:10264-10269. 
35. McManus DP: Prospects for development of a transmission blocking vaccine against Schistosoma japonicum. Parasite Immunol 2005, 27:297-308.

36. Capron A, Riveau G, Capron M, Trottein F: Schistosomes: the road from host-parasite interactions to vaccines in clinical trials. Trends Parasitol 2005, 21:143-149.

37. Fonseca CT, Cunha-Neto E, Goldberg AC, Kalil J, de Jesus AR, Carvalho EM, Correa-Oliveira R, Hammer J, Sidney J, Sette A, Oliveira SC: Identification of paramyosin $\mathrm{T}$ cell epitopes associated with human resistance to Schistosoma mansoni reinfection. Clin Exp Immunol 2005, 142:539-547.

38. Li GF, Wang Y, Zhang ZS, Wang XJ, Ji MJ, Zhu X, Liu F, Cai XP, Wu HW, WU GL: Identification of immunodominant Th1-type $T$ cell epitopes from Schistosoma japonicum $28 \mathrm{kDa}$ glutathione-S-transferase, a vaccine candidate. Acta Biochim Biophys Sin (Shanghai) 2005, 37:751-758.

39. Li Y, Auliff A, Jones MK, Yi X, McManus DP: Immunogenicity and immunolocalization of the $22.6 \mathrm{kDa}$ antigen of Schistosoma japonicum. Parasite Immunol 2000, 22:415-24.

40. Wu ZD, Lu ZY, Yu XB: Development of a vaccine against Schistosoma japonicum in China: a review. Acta Trop 2005, 96:106-116.

41. Bickle $\mathrm{QD}$, Bogh $\mathrm{HO}$, Johansen MV, Zhang Y: Comparison of the vaccine efficacy of gamma-irradiated Schistosoma japonicum cercariae with the defined antigen Sj62(IrV-5) in pigs. Vet Parasitol 2001, 100:51-62.

42. Jiz M, Wu HW, Meng R, Pond-Tor S, Reynolds M, Friedman JF, Olveda R, Acosta L, Kurtis JD: Pilot-scale production and characterization of paramyosin, a vaccine candidate for schistosomiasis japonica. Infect Immun 2008, 76:3164-3169.

43. Sette A, Fikes J: Epitope-based vaccines: an update on epitope identification, vaccine design and delivery. Curr Opin Immunol 2003, 15:461-470.

44. Gold DP, Vainiene M, Celnik B, Wiley S, Gibbs C, Hashim GA, Vandenbark AA, Offner $\mathrm{H}$ : Characterization of the immune response to a secondary encephalitogenic epitope of basic protein in Lewis rats. II. Biased T cell receptor $\mathrm{V}$ beta expression predominates in spinal cord infiltrating T cells. J Immunol 1992, 148:1712-1717.

45. Argiro L, Henri S, Dessein H, Kouriba B, Dessein AJ, Bourgois A: Induction of a protection against $S$. mansoni with a MAP containing epitopes of Sm37-GAPDH and Sm10-DLC. Effect of coadsorption with GM-CSF on alum. Vaccine 2000, 18:2033-2038.

46. Kedzierski L, Black CG, Goschnick MW, Stowers AW, Coppel RL: Immunization with a combination of merozoite surface proteins $4 / 5$ and 1 enhances protection against lethal challenge with Plasmodium yoelii. Infect Immun 2002, 70:6606-6613.

47. Ben-Yedidia T, Tarrab-Hazdai R, Schechtman D, Arnon R: Intranasal administration of synthetic recombinant peptide-based vaccine protects mice from infection by Schistosoma mansoni. Infect Immun 1999, 67:4360-4366.

48. Zhang Y, Taylor MG, Johansen MV, Bickle QD: Vaccination of mice with a cocktail DNA vaccine induces a Th1-type immune response and partial protection against Schistosoma japonicum infection. Vaccine 2001, 20:724-730.

49. Yang W, Jackson DC, Zeng Q, McManus DP: Multi-epitope schistosome vaccine candidates tested for protective immunogenicity in mice. Vaccine 2000, 19:103-113.

50. Herzenberg LA, Tokuhisa T, Parks DR, Herzenberg LA: Epitope-specific regulation. II. A bistable, Igh-restricted regulatory mechanism central to immunologic memory. J Exp Med 1982, 155:1741-1753.

51. Herzenberg LA, Tokuhisa T: Epitope-specific regulation. I. Carrier-specific induction of suppression for $\operatorname{lgG}$ anti-hapten antibody responses. J Exp Med 1982, 155:1730-1740.

52. Li YS, Ross AG, Sleigh AC, Li Y, Waine GJ, Williams GJ, Tanner M, McManus DP: Antibody isotype responses, infection and re-infection for Schistosoma japonicum in a marshland area of China. Acta Trop 1999, 73:79-92.

53. Beaver JE, Bourne PE, Ponomarenko JV: EpitopeViewer: a Java application for the visualization and analysis of immune epitopes in the Immune Epitope Database and Analysis Resource (IEDB). Immunome research 2007, 3:3.

54. Wilkins MR, Gasteiger E, Bairoch A, Sanchez JC, Williams KL, Appel RD, Hochstrasser DF: Protein identification and analysis tools in the ExPASy server. Methods in molecular biology (Clifton, NJ) 1999, 112:531-552.
55. Yang $X, Y u X:$ An introduction to epitope prediction methods and software. Reviews in medical virology 2009, 19:77-96.

56. Xu HB, Xu W, Chu YW, Wang Y, Xiong S: Single B or T-cell epitope-based DNA vaccine using modified vector induces specific immune response against hepadnavirus. Immunol Lett 2005, 99:186-192.

doi:10.1186/1756-3305-3-109

Cite this article as: Wang et al:: The nature and combination of subunits used in epitope-based Schistosoma japonicum vaccine formulations affect their efficacy. Parasites \& Vectors 2010 3:109.

\section{Submit your next manuscript to BioMed Central and take full advantage of:}

- Convenient online submission

- Thorough peer review

- No space constraints or color figure charges

- Immediate publication on acceptance

- Inclusion in PubMed, CAS, Scopus and Google Scholar

- Research which is freely available for redistribution 